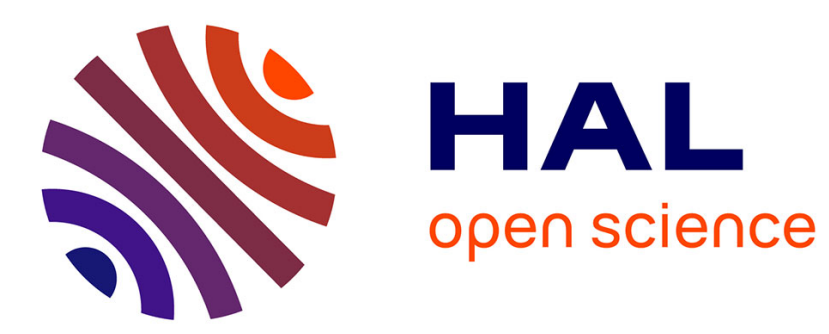

\title{
Facile and selective covalent grafting of an RGD-peptide to electrospun scaffolds improves HUVEC adhesion
}

\author{
Monica Dettin, Annj Zamuner, Martina Roso, Giovanna Iucci, Valérie
}

Samouillan, Roberta Danesin, Michele Modesti, Maria Teresa Conconi

\section{- To cite this version:}

Monica Dettin, Annj Zamuner, Martina Roso, Giovanna Iucci, Valérie Samouillan, et al.. Facile and selective covalent grafting of an RGD-peptide to electrospun scaffolds improves HUVEC adhesion. Journal of Peptide Science, 2015, vol. 21 ( $\mathrm{n}^{\circ} 10$ ), pp. 786-795. 10.1002/psc.2808 . hal-01345999

\author{
HAL Id: hal-01345999 \\ https://hal.science/hal-01345999
}

Submitted on 18 Jul 2016

HAL is a multi-disciplinary open access archive for the deposit and dissemination of scientific research documents, whether they are published or not. The documents may come from teaching and research institutions in France or abroad, or from public or private research centers.
L'archive ouverte pluridisciplinaire HAL, est destinée au dépôt et à la diffusion de documents scientifiques de niveau recherche, publiés ou non, émanant des établissements d'enseignement et de recherche français ou étrangers, des laboratoires publics ou privés. 


\section{Open Archive TOULOUSE Archive Ouverte (OATAO)}

OATAO is an open access repository that collects the work of Toulouse researchers and makes it freely available over the web where possible.

This is an author-deposited version published in : http://oatao.univ-toulouse.fr/ Eprints ID : 15718

To link to this article : dx.doi.org/10.1002/psc.2808

URL : http://dx.doi.org/10.1002/psc.2808

To cite this version : Dettin, Monica and Zamuner, Annj and Roso, Martina and Iucci, Giovanna and Samouillan, Valérie and Danesin, Roberta and Modesti, Michele and Conconi, Maria Teresa Facile and selective covalent grafting of an RGD-peptide to electrospun scaffolds improves HUVEC adhesion. (2015) Journal of Peptide Science, vol. 21 ( $\left.\mathrm{n}^{\circ} 10\right)$. pp. 786-795. ISSN 1075-2617

Any correspondence concerning this service should be sent to the repository administrator: staff-oatao@ listes-diff.inp-toulouse.fr 


\title{
Facile and selective covalent grafting of an RGD-peptide to electrospun scaffolds improves HUVEC adhesion
}

\author{
Monica Dettin, ${ }^{\text {a* Annj Zamuner, }}{ }^{a}$ Martina Roso, ${ }^{a}$ Giovanna lucci, ${ }^{b}$ \\ Valerie Samouillan, ${ }^{C}$ Roberta Danesin, ${ }^{a}$ Michele Modesti ${ }^{a}$ \\ and Maria Teresa Conconi ${ }^{\mathrm{d}}$
}

The development of a biomimetic surface able to promote endothelialization is fundamental in the search for blood vessel substitutes that prevent the formation of thrombi or hyperplasia. This study aims at investigating the effect of functionalization

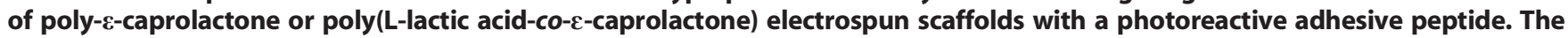
designed peptide sequence contains four Gly-Arg-Gly-Asp-Ser-Pro motifs per chain and a p-azido-Phe residue at each terminus. Different peptide densities on the scaffold surface were obtained by simply modifying the peptide concentration used in pretreatment of the scaffold before UV irradiation.

Scaffolds of poly- $\varepsilon$-caprolactone embedded with adhesive peptides were produced to assess the importance of peptide covalent grafting.

Our results show that the scaffolds functionalized with photoreactive peptides enhance adhesion at $24 \mathrm{~h}$ with a dosedependent effect and control the proliferation of human umbilical vein endothelial cells, whereas the inclusion of adhesive peptide in the electrospun matrices by embedding does not give satisfactory results.

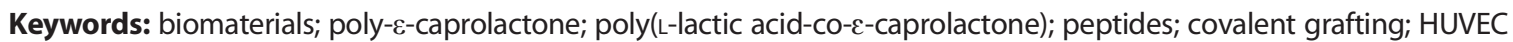

\section{Introduction}

Cardiovascular diseases (CVDs) are the leading cause of death in Western countries, and the need for vascular substitutes continues to grow [1]. Although autologous vessels, such as the internal mammary artery, radial artery, or saphenous vein, are considered the golden standard for the replacement of malfunctioning or diseased blood vessels, their availability is limited especially in elderly patients and because of concomitant diseases [2]. Synthetic materials, such as Dacron ${ }^{\circledR}$ and expanded polytetrafluoroethylene (ePTFE), can be used successfully to substitute large diameter vessels [3]. However, they are not as suitable for small diameter $(<6 \mathrm{~mm})$ arterial grafts because of their thrombogenicity and increased rate of infections and inflammation [4]. Three main types of tissueengineered blood vessels (TEBVs) have been designed for vascular regeneration: (i) biodegradable synthetic polymer-based constructs, (ii) cell self-assembly blood vessels, and (iii) decellularized tissue grafts [5].

Several polymers have been used to obtain TEBVs: poly (dimethylsiloxane), poly- $\varepsilon$-caprolactone (PCL), poly(methyl methacrylate), poly-L-lactic acid (PLLA), polyglycolic acid, poly(glycerol sebacate), and polyvinyl alcohol $[6,7]$. Several studies have shown that the behavior of vascular cells (fibroblasts, endothelial, and muscle cells) depends on the topography of biomaterial: presence of fibers or pores, pore size of the fibers, spacing between these elements, roughness, orientation of the fibers, and microscale or nanoscale [8]. These features can be produced in a wide range of biomaterials through various techniques, such as photolithography, etching, molding, particulate leaching, and electrospinning [9]. The latter can be used to create fibers with diameters down to the nanoscale range, possessing high porosity and spatial interconnectivity and developing a large specific surface area for loading of bioactive molecules [10].

To guarantee an in vivo long-term patency of TEBVs, intimal hyperplasia and graft occlusion must be avoided, and a continuous lining of endothelial cells (ECs) on the luminal surface of TEBVs seems to be essential because it represents a physical barrier that is able to prevent platelet adhesion and the activation of the coagulation cascade [11]. Indeed, in vivo studies have shown that in vitro re-endothelialized conduits lack thrombogenic complications [12].

\footnotetext{
* Correspondence to: Monica Dettin, Department of Industrial Engineering, University of Padova, Via Marzolo, 935131 Padova, Italy.

E-mail: monica.dettin@unipd.it

a Department of Industrial Engineering, University of Padova, Padova, Italy

b Department of Physics, University Roma Tre, Rome, Italy

c Inter-university Centre for Materials Research and Engineering, University Toulouse-Paul Sabatier, Toulouse, France

d Department of Pharmaceutical and Pharmacological Sciences, University of Padova, Padova, Italy
} 
Although in vitro re-endothelization of the grafts remains timeconsuming, the capability of the biomaterial to induce the in vivo adhesion of ECs derived from both the neighboring tissues or circulating progenitors seems to be a desirable effect. Thus, polymer surfaces have been modified with cell adhesion sequences derived from extracellular matrix (ECM) macromolecules, such as fibronectin, laminin, and type-1 collagen [13]. Among these, the RGD peptide is the main adhesion motif used in vascular tissue engineering [14]. Covalent linking and simple coating were carried out to modify the surface. The former approach allows peptides to be uniformly distributed throughout the biomaterial, whereas the latter is less effective in terms of quantity of molecules adsorbed. Starting from these considerations, this study aims at developing a functionalized polymeric surface able to promote endothelialization and consequently mimic the lumen of a blood vessel. Electrospun matrices of two bioresorbable polymers - poly- $\varepsilon^{-}$ caprolactone and the 70:30 copolymer poly- $\varepsilon$-caprolactone-copolylactic acid ( $P(L L A-C L)$ - were taken into consideration. These surfaces became biomimetic through enrichment with a linear adhesive peptide carrying four Gly-Arg-Gly-Asp-Ser-Pro (GRGDSP) motifs per chain, designed in our laboratory, that showed higher capacity to promote osteoblast adhesion when compared with branched peptides or sequences with a single motif (RGD or GRGDSPK) $[15,16]$. Later in this article, it will be referred as RGDpeptide for the sake of simplification. Two different strategies were used to create the biomimetic surfaces: (i) covalent bond for photoactivation of specific surface azido groups inserted at the end of the peptide sequence (Figures 1 and 2) and (ii) inclusion of adhesive peptides in the polymeric solutions before electrospinning (only in the case of PCL scaffolds - Figure 2).
In vitro assays with endothelial cells (human umbilical vein endothelial cells (HUVEC)) were performed to test the potential of biomimetic surfaces to promote adhesion and control proliferation.

\section{Experimental Section}

\section{Materials}

The solid support resins Sasrin and Amide MBHA were from Novabiochem (Merck KGaA, Darmstadt, Germany). The Fmoc protected amino acids were from Novabiochem (Merck KGaA, Darmstadt, Germany). The coupling reagents 2-(1H-benzotriazole1-yl)-1,1,3,3-tetramethyluronium hexafluorophosphate (HBTU) and 1-hydroxybenzotriazole (HOBt) were from Advanced Biotech (Seveso, Ml, Italy). N,N-Diisopropylethylamine (DIEA) and piperidine were from Biosolve (Leenderweg, Valkenswaard, Netherlands). Triethoxysilane (TES) was from Sigma-Aldrich (Steinheim, Germany). Solvents such as $N, N$-dimethylformamide (DMF), trifluoroaceticacid (TFA), N-methyl-2-pyrrolidone (NMP), and dichloromethane (DCM) were from Biosolve (Leenderweg, Valkenswaard, Netherlands). Poly- $\varepsilon$-caprolactone $(\mathrm{Mn}=60 \mathrm{KDa})$, acetonitrile, and 1,1,1-3,3,3-hexafluoro-2-propanol (HFIP) were purchased from Sigma-Aldrich (Steinheim, Germany). The copolymer poly(L-lactic acid-co- $\varepsilon$-caprolactone) (70:30) was purchased by PURAC biochem (Gorinchen, Holland).

Phosphate-buffered saline (PBS) tablets were purchased from Gibco Invitrogen Corp. (Paisley, UK). The Endothelial Cell Growth Medium MV2 was purchased from PromoCell GmbH (Heidelberg, Germany). Cell strainer, tissue culture-treated dishes, and fibronectin were from BD Biosciences (San Jose, CA, USA), whereas 3-(4,5-

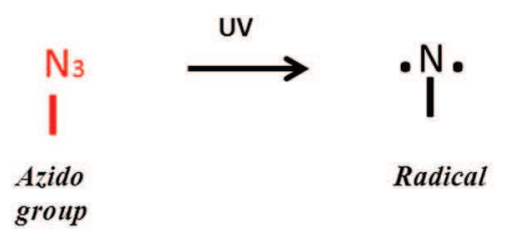

$\mathrm{H}-\mathrm{Phe}\left(\mathrm{p}-\mathrm{N}_{3}\right)-(\text { Gly-Arg-Gly-Asp-Ser-Pro })_{4}-\mathrm{Phe}\left(\mathrm{p}-\mathrm{N}_{3}\right)-\mathrm{NH}_{2}=\star \mathrm{RGD}$ RGD $\mathrm{RGD}-\mathrm{RGD} \downarrow$

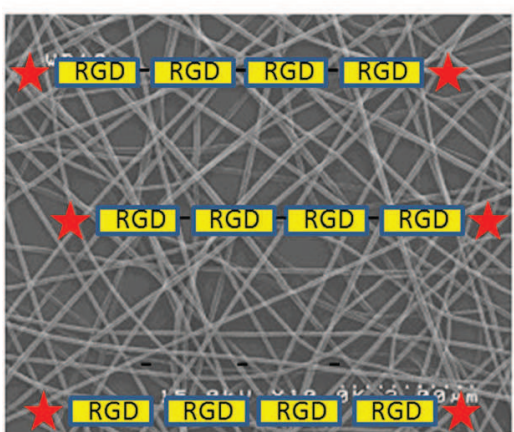

Adsorbed peptides

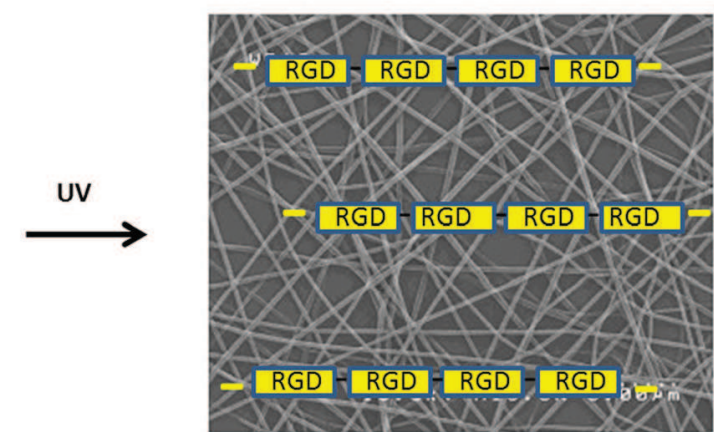

Covalently bound peptides

Figure 1. Schematic representation of covalent grafting of photoreactive peptide $N_{3} R G D$ to electrospun scaffold surfaces. The photoreactive peptide is physisorbed on the surface of the scaffold, and then the UV irradiation induces the formation of nitrenes from azido groups inserted at the ends of the peptide chain causing the formation of covalent bonds between the peptide and the polymer. 


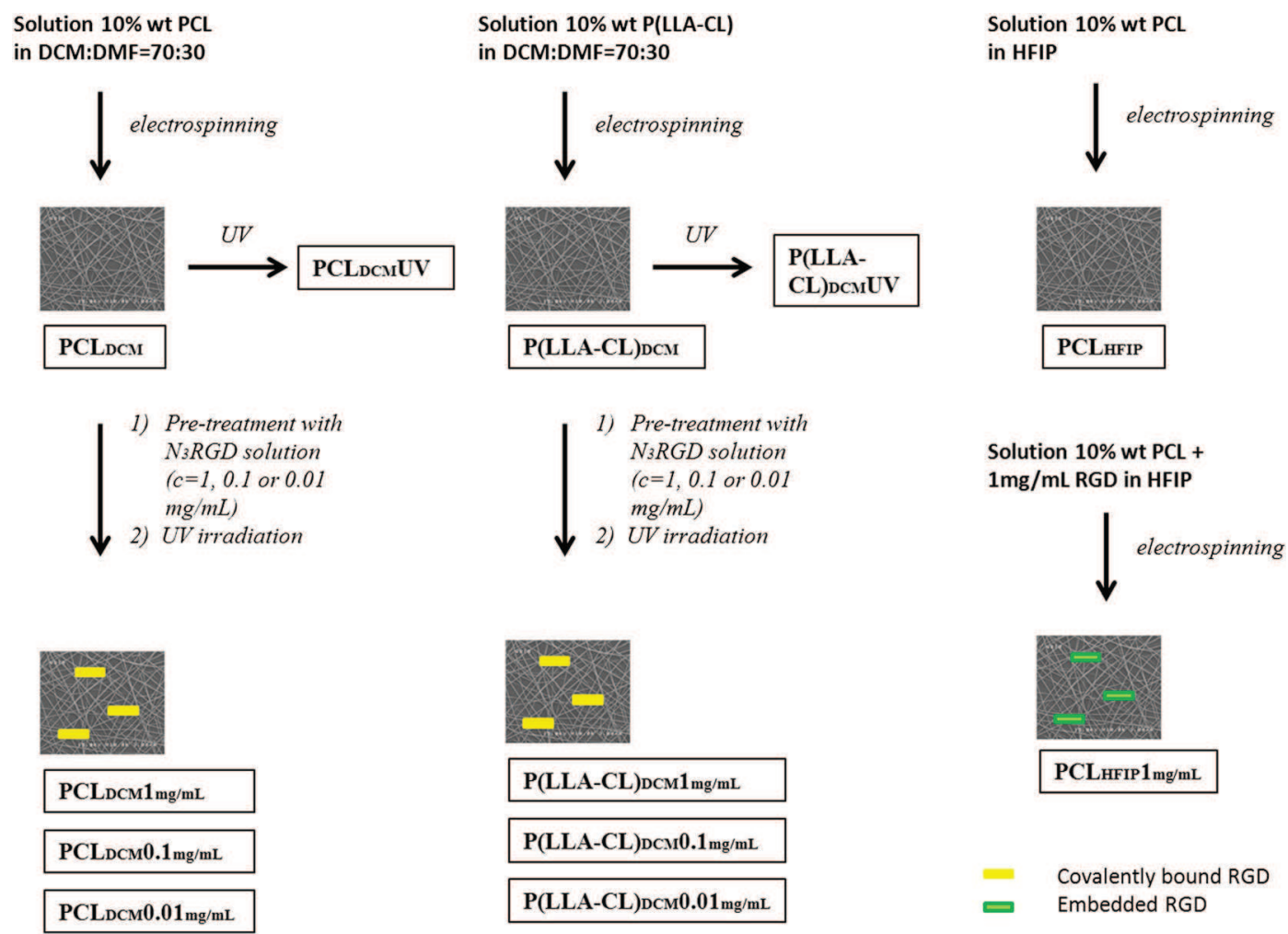

Figure 2. Production route of the different scaffolds and their denomination.

dimethylthiazol-2-yl)-2,5-dimethyltetrazolium bromide-tetrazolium dye (MTT) was provided by Sigma-Aldrich (St. Louis, MO, USA).

\section{Methods}

Peptide design and synthesis

The peptide named $\mathrm{N}_{3} \mathrm{RGD}$ (sequence: $\mathrm{H}-\mathrm{Phe}\left(\mathrm{p}-\mathrm{N}_{3}\right)$-Gly-Arg-GlyAsp-Ser-Pro-Gly-Arg-Gly-Asp-Ser-Pro-Gly-Arg-Gly-Asp-Ser-Pro-GlyArg-Gly-Asp-Ser-Pro-Phe $\left(\mathrm{p}-\mathrm{N}_{3}\right)-\mathrm{NH}_{2}$ ) is characterized by the introduction of two aryl azides at the termini of a linear peptide composed by four GRGDSP motifs. The introduction of two aryl azides per chain was realized to increase successful grafting. The sites of introduction of photoreactive groups, used to anchor the adhesive sequence, preserves the pattern of adhesive motifs that are functional to biological activity observed. The peptide $\mathrm{N}_{3} \mathrm{RGD}$ was synthesized as a p-amino analog with Fmoc chemistry using a Syro-I synthesizer (Multisyntech Gmbh, Germany) on Rink amide MBHA resin $(0.66 \mathrm{mmol} / \mathrm{g}$ substitution, $0.13 \mathrm{mmol}$ scale). The condensation was carried out via HBTU/HOBt using double couplings ( 5 eq. for each amino acid insertion). The side-chain protective groups were as follows: OtBu for Asp, Pmc for Arg, and tBu for Ser Boc for Phe $\left(\mathrm{p}-\mathrm{NH}_{21}\right)$. The peptide was cleaved from the resin and side-chain deprotected with $9.5 \mathrm{ml}$ trifluoroacetic acid, $0.25 \mathrm{ml}$ TES, and $0.25 \mathrm{ml} \mathrm{H}_{2} \mathrm{O}$ for $2 \mathrm{~h} 15 \mathrm{~min}$ in the dark. After the conversion of amino groups into azido groups by reaction in solution with sodium nitrite and sodium azide [17], the N-terminal Fmoc-protected crude product was Fmoc-deprotected and then purified by reverse phase-high-performance liquid chromatography (RP-HPLC) without use of UV-detector. The purified peptide had a 92\% homogeneity as resulted by the integration of chromatography pattern (conditions: column Vydac $\mathrm{C}_{18}$ 218TP54 protein and peptide
$(5 \mu \mathrm{m}, 300 \AA, \quad 4.6 \times 250 \mathrm{~mm}) ; \quad$ flow rate $=1.0 \mathrm{ml} / \mathrm{min}$; eluent $\mathrm{A}=0.05 \%$ TFA in $\mathrm{H}_{2} \mathrm{O}$ MilliQ; eluent $\mathrm{B}=0.05 \%$ TFA in $\mathrm{CH}_{3} \mathrm{CN}$; gradient $=13-23 \%$ B over $20 \mathrm{~min}$; and detector $214 \mathrm{~nm}$ ).

The peptide identity was established by electrospray ionizationtime of flight (ESI-TOF) mass analysis (theoretical mass: 2671.70 Da; experimental mass: 2671.18 Da).

The peptide named RGD (sequence: H-Gly-Arg-Gly-Asp-Ser-ProGly-Arg-Gly-Asp-Ser-Pro-Gly-Arg-Gly-Asp-Ser-Pro-Gly-Arg-Gly-AspSer-Pro-Lys-OH) was synthesized and purified as previously described [15]. The peptide homogeneity grade was $97.4 \%$ (conditions: column Vydac $\mathrm{C}_{18}$ 218TP54 protein and peptide; flow rate $=1.0 \mathrm{ml} / \mathrm{min}$; eluent $A=0.05 \%$ TFA in $\mathrm{H}_{2} \mathrm{O}$ MilliQ; eluent $\mathrm{B}=0.05 \%$ TFA in $\mathrm{CH}_{3} \mathrm{CN}$; gradient $=4-14 \% \mathrm{~B}$ over $20 \mathrm{~min}$; and detector $214 \mathrm{~nm}$ ). ESI-TOF mass analysis confirmed the identity of the product (theoretical mass: $2424.51 \mathrm{Da}$; experimental mass: 2424.15 Da).

\section{Electrospinning}

Three different set of electrospun samples (Figure 2) were obtained by processing the following polymeric solutions:

- $10 \% \mathrm{wt} / \mathrm{wt} \mathrm{P}(\mathrm{LLA}-\mathrm{CL})(70-30)$ solution in $\mathrm{DCM}: \mathrm{DMF}=70: 30$ $w t / w t ;$

- $25 \% \mathrm{PCL}$ wt/wt solution in DCM:DMF $=70: 30 \mathrm{wt} / \mathrm{wt}_{\text {; }}$

- $10 \%$ wt PCL with or without $1 \mathrm{mg} / \mathrm{ml}$ RGD in HFIP.

The process conditions in terms of flow rate, distance between electrodes, and applied voltage, are summarized in Table 1 for each polymer/solvent system. All the samples were collected for 1-h time.

The aluminum foil $(15 \times 15 \mathrm{~cm})$ used as the collector was cut in circular samples of $1.2-\mathrm{cm}$ diameter. 


\begin{tabular}{|lcccc|}
\hline $\begin{array}{l}\text { Table 1. Process parameters for electrospinning } \\
\begin{array}{l}\text { Polymer/solvent } \\
\text { system }\end{array} \\
\end{array}$ & Flow rate Distance Applied voltage & Needle i.d. \\
& $(\mathrm{ml} / \mathrm{h})$ & $(\mathrm{cm})$ & $(\mathrm{kV})$ & $(\mathrm{mm})$ \\
\hline P(LLA-CL)/DMC-DMF & 1 & 10 & 8 & 0.4 \\
PCL/DMC-DMF & 1 & 15 & 8 & 0.4 \\
PCL/HFIP & 1 & 15 & 16 & 0.4 \\
\hline
\end{tabular}

\section{Scaffold sampling}

The samples of copolymer were not cut directly on polymercovered aluminum foil because the copolymer shrinks itself once placed in water. Consequently, the scaffold was immersed in water, detached from the aluminum support by peeling, and successively dried and cut. The copolymer resulted difficult to manipulate for its tendency to curl. The samples of PLC did not present these problems.

\section{Surface crosslinking through photoreactive adhesive peptides}

The peptide pre-conditioning was obtained through the incubation of samples with a solution of $1 \mathrm{mg} \mathrm{N} \mathrm{N}_{3} \mathrm{RGD}$ in $1 \mathrm{ml}$ MilliQ water, $0.1 \mathrm{mg} / \mathrm{ml}$, or $0.01 \mathrm{mg} / \mathrm{ml}$ for $1 \mathrm{~h}$ at room temperature (Figure 2). The samples were dried under vacuum in the presence of $\mathrm{P}_{2} \mathrm{O}_{5}$. Each sample was irradiated for $30 \mathrm{~min}$ at $254 \mathrm{~nm}$ (distance from the lamp, $1 \mathrm{~cm}$ - model UVSL-15 mineralight lamp $220 \mathrm{~V}, 50 \mathrm{~Hz}$, 0.12 AMPS, Ultraviolet Products INC, San Gabriel, CA, USA) [18]. The samples were extensively washed with MilliQ water and dried under vacuum.

\section{Scanning electron microscopy}

Electrospun scaffolds were sputter coated with carbon (EMITECH K950x Turbo Evaporator, EBSciences, East Granby, CT) and observed under SEM (Cambridge Stereoscan 440 SEM, Cambridge, UK). Images were taken at magnifications of $30000 \times$ with an accelerating voltage of $15 \mathrm{kV}$. The diameter range of the fabricated nanofibers was measured using image analysis software (ImageJ, National Institutes of Health, Bethesda, MD,USA). For each sample, three images at different magnification and in three different zones of the sample were taken.

\section{$X$-ray photoelectron spectroscopy measurements}

X-ray photoelectron spectroscopy (XPS) investigations were performed in an instrument of our own construction and design equipped with a 150-mm mean radius hemispherical electron analyzer and a 16-channel detector. Mg Ka non-monochromatized Xray radiation $(\mathrm{h} v=1253.6 \mathrm{eV})$ was used to record peptide ( $\mathrm{C} 1 \mathrm{~s}$, $\mathrm{N} 1 \mathrm{~s}$, and $\mathrm{O} 1 \mathrm{~s})$ and polymer (C1s and $\mathrm{O} 1 \mathrm{~s})$ core-level spectra on the respective samples. XPS spectra of $\mathrm{N}_{3} \mathrm{RGD}$ were also recorded as reference. In all the investigated samples, the Al2p signal from the Al foil substrate was too low to be detected; this indicated the presence of a thick mat of polymer nanofibers. The spectra were energy referenced to the $\mathrm{C} 1$ signal of aliphatic carbons located at a binding energy (BE) of $285.0 \mathrm{eV}$ [19]. The standard deviation on the measured BE values was $0.1 \mathrm{eV}$. Atomic ratios $( \pm 10 \%)$ were calculated from the peak intensities with Scofield's cross sections and experimentally determined sensitivity factors. A curve-fitting analysis of the C1s, N1s, and O1s spectra was performed with Gaussian curves as fitting functions.

\section{Contact angle measurements}

Contact angles (CA) were measured using a SURTENS angulometer (OEG, GmbH, Frankfurt, Germany) at $25^{\circ} \mathrm{C} \pm 0.5^{\circ} \mathrm{C}$ and for a relative humidity of $30 \% \pm 2 \%$. One sample for each kind of scaffold was set onto a silica slide, and droplets of PBS $(3 \mu \mathrm{l})$ were dispensed onto the scaffold for contact angle measurement.

\section{Differential scanning calorimetry}

Differential scanning calorimetry apparatus (DSC from Pyris Elmer) was calibrated using $\mathrm{Hg}$ and In as standards, resulting in temperature accuracy $\pm 0.1^{\circ} \mathrm{C}$ and enthalpy accuracy $\pm 0.2 \mathrm{~J} / \mathrm{g}$.

Poly(L-lactide-co- $\varepsilon$-caprolactone) samples in the solid state, $5 \mathrm{mg}$ in weight, were set into aluminum pans and submitted to the following temperature program under nitrogen flow: cooling at $-20^{\circ} \mathrm{C} / \mathrm{min}$ until $-100^{\circ} \mathrm{C}$ and successive heating from -100 to $200^{\circ} \mathrm{C}$ at $10^{\circ} \mathrm{C} / \mathrm{min}$ resulting in a first DSC scan. After quenching at $-100^{\circ} \mathrm{C}$, this temperature program is repeated resulting in a second DSC scan.

Chromatography determination of $R G D$ release from the scaffold $P C L_{\text {HFIP } 1 \mathrm{mg} / \mathrm{ml}}$

The assay was carried out on three different scaffolds ( $\mathrm{PCL}_{\text {HFIP1 } 1 \mathrm{mg} / \mathrm{ml}}$ ) prepared with $1 \mathrm{mg} / \mathrm{ml}$ of RGD. Each sample was cut and its surface area determined. The samples were separated from the aluminum foil and weighed. Each sample was left in a glass tube with $1 \mathrm{ml}$ of PBS at $37^{\circ} \mathrm{C}$ : at each time point, a sample $(0.115 \mathrm{ml})$ of solution was picked up and injected in HPLC to determine the peak area. The same volume was replaced by PBS. The peak area was correlated to RGD nmoles through a weighted titration chromatographic curve obtained injecting in HPLC known quantities of RGD. The chromatographyc conditions used were as follows: column, Vydac-C18 $(5 \mu \mathrm{m}, 300 \AA, 4.6 \times 250 \mathrm{~mm}$ Grace Vydac, Hesperia, CA); eluent $A\left(\mathrm{H}_{2} \mathrm{O}\right.$ MilliQ with $0.05 \%$ TFA), eluent $B\left(\mathrm{CH}_{3} \mathrm{CN}, 0.05 \%\right.$ TFA); gradient, from $0 \%$ to $80 \%$ of $B$ in $25 \mathrm{~min}$; flow rate, $1 \mathrm{ml} / \mathrm{min}$; and detector, $214 \mathrm{~nm}$.

\section{Biological Assays}

\section{Cell cultures}

Primary cultures of human umbilical vein endothelial cells were obtained by enzymatic digestion of umbilical vein endothelial layer with a $0.1 \%$ collagenase IV solution. The cells were seeded on Petri dishes previously coated with $1 \mu \mathrm{g} / \mathrm{ml}$ fibronectin and cultured with Endothelial Cell Growth Medium $\mathrm{MV}_{2}$ supplemented with $5 \%$ fetal calf serum (FCS), $1 \mu \mathrm{g} / \mathrm{ml}$ ascorbic acid, $10 \mathrm{ng} / \mathrm{mL}$ hFGF-2, $5 \mathrm{ng} / \mathrm{mL}$ hEGF, hydrocortisone $0.2 \mu \mathrm{g} / \mathrm{ml}, 20 \mathrm{ng} / \mathrm{ml} \mathrm{R}^{3}-\mathrm{IGF}-1,0.5 \mathrm{ng} / \mathrm{ml}$ VEGF (endothelial $\mathrm{MV}_{2}$ medium kit), and $1 \%$ antibiotic solution, containing $10 \mathrm{ng} / \mathrm{ml}$ streptomycin sulfate, $250 \mathrm{ng} / \mathrm{ml}$ amphotericin-B, and $100 \mathrm{U} / \mathrm{ml}$ penicillin. This medium was referred as complete medium. Cultures were incubated at $37^{\circ} \mathrm{C}$ in a humidified atmosphere. HUVECs were used until the fourth passage and harvested at $80 \%$ confluence.

\section{MTT assay}

The 3-(4,5-dimethylthiazol-2-yl)-2,5-dimethyltetrazolium bromide tetrazolium dye assay was used to evaluate cell adhesion at $24 \mathrm{~h}$ and cell proliferation at 3 and 7 days. HUVECs $\left(3 \times 10^{5}\right.$ cells $\left./ \mathrm{cm}^{2}\right)$ were seeded on $\mathrm{PCL}_{\mathrm{HFIP}}, \mathrm{PCL}_{\mathrm{DCM}}$, and $\mathrm{P}(\mathrm{LLA}-\mathrm{CL})_{\mathrm{DCM}}$ lacking adhesive peptides or containing them in various concentrations $(1,0.1$, and $0.01 \mathrm{mg} / \mathrm{ml})$. The peptide named RGD was incorporated in 
$\mathrm{PCL}_{\mathrm{HFIP}}$, whereas $\mathrm{PCL}_{\mathrm{DCM}}$ and $\mathrm{P}(\mathrm{LLA}-\mathrm{CL})_{\mathrm{DCM}}$ carried the photoactive peptide $\mathrm{N}_{3} R G D$. Furthermore, some cultures grew on $\mathrm{PCL}_{D C M}$, and $\mathrm{P}$ $(\mathrm{LLA}-\mathrm{CL})_{\mathrm{DCM}}$ without peptides and treated with UV light. Before seeding, all scaffolds were put onto wells of 12 -well plates, and cells were cultured by using Basal MV2 Medium supplemented with 1\% FCS and lacking growth factors. Briefly, after $24 \mathrm{~h}, 3$ and 7 days from seeding, cells were treated with MTT $(0.50 \mathrm{mg} / \mathrm{ml}$; Sigma $)$ for $4 \mathrm{~h}$. Formazane precipitates were dissolved in acidic 2-propanol $(0.04 \mathrm{M} \mathrm{HCl}$ in 2-propanol; Sigma) and optical density was measured at $570 \mathrm{~nm}$, using a Microplate autoreader EL 13 (BIO-TEK instruments Inc., Winooski, Vermont, USA). The linearity of absorbance of formazan over a range of $3 \times 10^{3}-20 \times 10^{4}$ cells was established by determining the linear coefficient (0.9858). Results were expressed as either percent of control cultures grown on polymers without peptides (taken as 100) or cell number. Their statistical comparison was performed by analysis of variance, followed by Student's $t$-test.

\section{Results}

\section{Peptide Synthesis}

Initially, the synthesis of the $\mathrm{N}_{3} \mathrm{RGD}$ peptide was carried out using Fmoc-Phe $\left(\mathrm{p}-\mathrm{N}_{3}\right)-\mathrm{OH}$, but this strategy did not produce the target peptide. Instead, the introduction of $\mathrm{Phe}\left(\mathrm{p}-\mathrm{NH}_{2}\right)$ residues and the following conversion of amino groups into azido groups produced a yield of the target peptide ( $30 \mathrm{mg}(11 \mu$ moles) with a purity grade $>95 \%$ with respect to a synthetic scale of 0.25 mmoles).

\section{Morphological Analysis by SEM}

In poly(L-lactide-co- $\varepsilon$-caprolactone) scaffolds, the fibers were randomly oriented, the diameter varied between 0.6 and $2 \mu \mathrm{m}$, and the mesh width varied between 3.5 and $20 \mu \mathrm{m}$ (Figure 3A).

The electrospun $\mathrm{PCL}$, obtained with the same solvent and with the same parameters applied for $\mathrm{P}(\mathrm{LLA}-\mathrm{CL})$, resulted in a nonwoven mat with many defects or beads. To produce the scaffold used for the biological assays, the SEM image of which was reported in Figure $3 \mathrm{~B}$, the concentration of the polymer solution, and the distance between the needle and the collector were increased (concentration from $10 \%$ to $25 \% \mathrm{wt} / \mathrm{wt}$ and distance from 10 to $15 \mathrm{~cm}$ ).

The scaffold showed a bimodal distribution of the fibers with a diameter between 1 and $3 \mu \mathrm{m}$ in the first case, and of a few hundred nanometers in the second case. The formation of fiber bundles produced a rough surface visible to the naked eye in which meshes of tens of $\mu \mathrm{m}$ alternate with meshes of hundreds of $\mu \mathrm{m}$. In the scaffold electrospun from a solution of PCL in HFIP, the fiber diameter varied from 0.1 to $0.2 \mu \mathrm{m}$ and presented rather dense meshes $(4 \mu \mathrm{m})$ (Fig. 3, C).
No morphological changes (data not shown) occurred through the enrichment of the polymer solution with peptides before electrospinning or surface treatment with photoactive peptide solution followed by irradiation.

\section{X-ray Photoelectron Spectroscopy Analysis}

The poly- $\varepsilon$-caprolactone and $\mathrm{P}(\mathrm{LLA}-\mathrm{CL})$ scaffolds and their biomimetic analogs obtained by adding three different concentration peptide solutions and irradiation were characterized by XPS. A detailed description of the data is reported in reference [20]. The study demonstrated the immobilization of the RGD peptide on the surface for both materials, as evidenced by the appearance of an $\mathrm{N} 1 \mathrm{~s}$ peak at $\mathrm{BE}=400.0 \mathrm{eV}$, in agreement with the expected value for amide nitrogens [19]; the N1s spectrum of pristine $\mathrm{N}_{3} R G D$ shows a single peak located at $400.0 \mathrm{eV}$, exactly. The N1s spectra recorded for both $\mathrm{PCL}$ and $\mathrm{P}(\mathrm{LLA}-\mathrm{CL})$ after incubation with peptide solution at $1.0 \mathrm{mg} / \mathrm{ml}$ are shown in Figure 4 (right). Table 2 shows the measured N/C and N/O atomic ratios for the two polymer films after peptide immobilization and for the reference $\mathrm{N}_{3} R G D$ peptide. The $\mathrm{N} 1 \mathrm{~s}$ signal can be detected even for the lowest peptide concentration $(0.01 \mathrm{mg} / \mathrm{ml})$. The amount of immobilized peptide, measured by the N/C and N/O ratios, increases with peptide concentration of the mother solution. A plot of the measured N/C and N/O ratios as a function of peptide concentration is also shown in Figure 4 (left); the trend is very similar for the two polymer films. However, the efficiency of peptide immobilization was low: the reaction yield was, even for the samples prepared with the highest peptide concentration solutions, less than $10 \%$ of the values calculated for the initial peptide quantity [20].

\section{Release of the Peptide RGD from PCL HFIP $1 \mathrm{mg} / \mathrm{ml}_{\text {Scaffold }}$}

A study of peptide release in solution $(10 \mathrm{~mm}$ sodium phosphate and $150 \mathrm{~mm} \mathrm{NaCl}$ buffer at $\mathrm{pH} 7.4$ ) at $37^{\circ} \mathrm{C}$ was performed for the $\mathrm{PCL}_{\text {HFIP }} 1 \mathrm{mg} / \mathrm{ml}$ scaffold (Figure 2 ) in which the peptide is not covalently linked to PCL.

The kinetics of peptide release showed that the concentration of the peptide solution reached a constant value after $15 \mathrm{~h}$ : the quantity of peptide released is about one third of the initial peptide quantity (Figure 5).

\section{Characterization of $\mathrm{P}(\text { LLA-PC) })_{D C M}$; $\mathrm{P}(\text { LLA-PC) })_{D C M} \mathrm{UV}$; $\mathrm{P}($ LLA-PC) DCM $0.01 \mathrm{mg} / \mathrm{ml} ; \mathrm{P}(\text { LLA-PC) })_{D C M} 0.1 \mathrm{mg} / \mathrm{ml}$, and P(LLA-PC) $)_{D C M} 1 \mathrm{mg} / \mathrm{ml}$}

The hydrophobicity of all P(LLA-CL) samples detailed in Figure 2 was evaluated, and their thermal transitions were determined in order to evaluate the effect of UV irradiation and peptide functionalization on these physical characteristics.
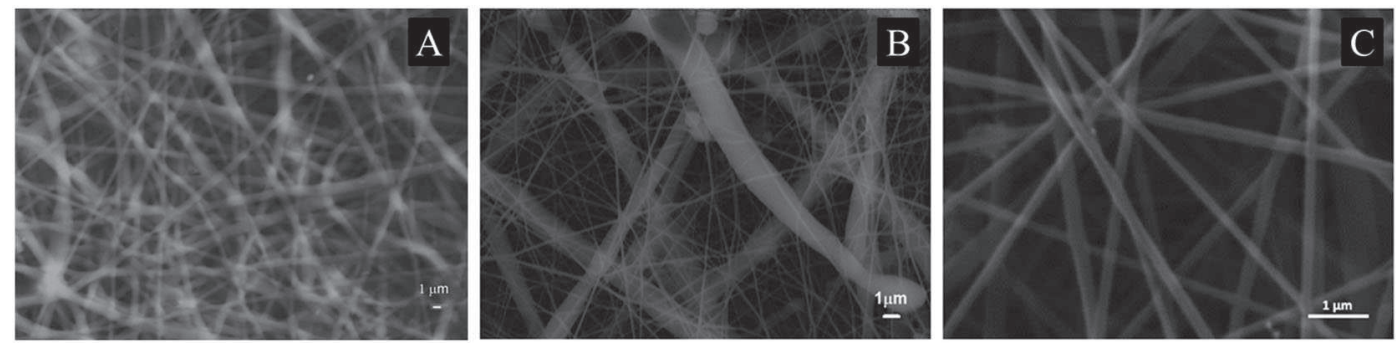

Figure 3. SEM images of electrospun scaffolds produced using (A) $25 \%$ (wt/wt) PCL in DCM/DMF (70:30 wt/wt); (B) 10\% (wt/wt) PCL in HFIP; and (C) 10\%

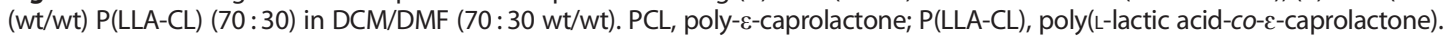



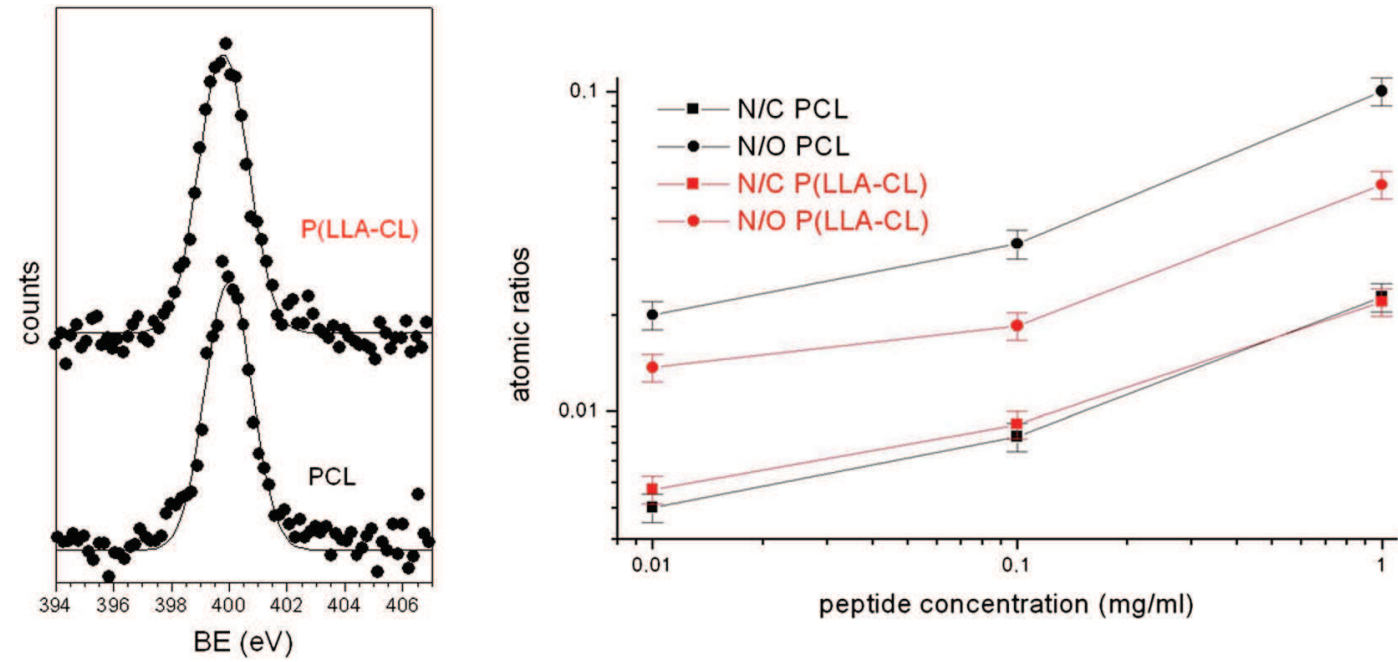

Figure 4. $\mathrm{N} 1 \mathrm{~s}$ spectra of $\mathrm{PCL}$ and $\mathrm{P}(\mathrm{LLA}-\mathrm{CL})$ films after incubation with $1.0 \mathrm{mg} / \mathrm{ml}$ peptide solution; markers represent experimental points and the line represent the fitting component (right). Plot of the measured atomic ratios (N/C and N/O) as a function of peptide concentration in the mother solution; both abscissa and ordinate are in log scale (left). Error bars $( \pm 10 \%)$ are also shown in the figure. PCL, poly- $\varepsilon$-caprolactone; $\mathrm{P}(\mathrm{LLA}-\mathrm{CL}), \mathrm{poly}(\mathrm{L}-\mathrm{lactic}$ acid-co- $\varepsilon-$ caprolactone).

\begin{tabular}{|c|c|c|}
\hline Sample & $\mathrm{N} / \mathrm{C}$ & $\mathrm{N} / \mathrm{O}$ \\
\hline $\mathrm{N}_{3} \mathrm{RGD}$ & 0.35 & 0.92 \\
\hline $\mathrm{PCL}_{\mathrm{DCM}} 0.01 \mathrm{mg} / \mathrm{ml}$ & 0.005 & 0.020 \\
\hline $\mathrm{PCL}_{\mathrm{DCM}} 0.1 \mathrm{mg} / \mathrm{ml}$ & 0.008 & 0.033 \\
\hline$P C L_{D C M} 1 \mathrm{mg} / \mathrm{ml}$ & 0.023 & 0.10 \\
\hline $\mathrm{P}(\mathrm{LLA}-\mathrm{CL})_{\mathrm{DCM}} 0.01 \mathrm{mg} / \mathrm{ml}$ & 0.006 & 0.014 \\
\hline$P(L L A-C L)_{D C M} 0.1$ mg/ml & 0.009 & 0.019 \\
\hline $\mathrm{P}(\mathrm{LLA}-\mathrm{CL})_{\mathrm{DCM}} 1 \mathrm{mg} / \mathrm{ml}$ & 0.022 & 0.057 \\
\hline
\end{tabular}

\section{Contact angle measurements}

The results of PBS CA measurements are reported in Table 3.

The measurements are quite reproducible and all the samples showed a high level of hydrophobicity, with CA values of about $120^{\circ}$.

\section{Differential scanning calorimetry}

The DSC thermograms of $\mathrm{P}(\mathrm{LLA}-\mathrm{CL})$ samples are reported in Figure 6 . The first DSC thermogram of initial $P(L L A-C L)$ samples

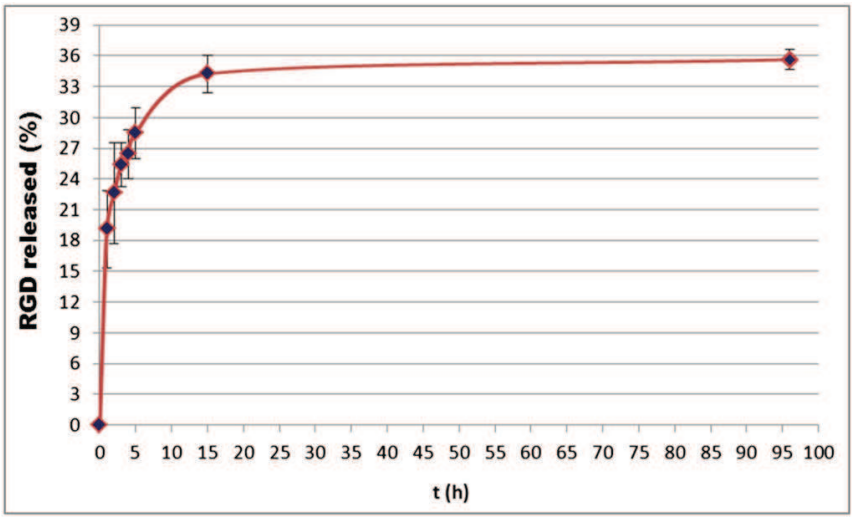

Figure 5. Release of RGD from $P C L_{\text {HFIP }} 1 \mathrm{mg} / \mathrm{ml}$ scaffold. $P C L$, poly-६caprolactone.

\begin{tabular}{|lccc|}
\hline \multicolumn{4}{|l|}{ Table 3. Contact angle measurements of $\mathrm{P}(\mathrm{LLA}-\mathrm{CL})$ scaffolds } \\
\hline Sample & $\mathrm{N}$ & Mean CA $\left(^{\circ}\right)$ & ${ }^{\circ}$ CA SD $\left(^{\circ}\right)$ \\
\hline Control P(LLA-CL) $)_{\mathrm{DCM}}$ & 3 & 118.9 & 0.52 \\
$\mathrm{P}(\mathrm{LLA}-\mathrm{CL})_{\mathrm{DCM}} \mathrm{UV}$ & 3 & 122.9 & 1.06 \\
$\mathrm{P}(\mathrm{LLA}-\mathrm{CL})_{\mathrm{DCM}} 0.01 \mathrm{mg} / \mathrm{ml}$ & 3 & 118.3 & 1.19 \\
$\mathrm{P}(\mathrm{LLA}-\mathrm{CL})_{\mathrm{DCM}} 0.1 \mathrm{mg} / \mathrm{ml}$ & 2 & 120.4 & 0.99 \\
$\mathrm{P}(\mathrm{LLA}-\mathrm{CL})_{\mathrm{DCM}} 1 \mathrm{mg} / \mathrm{ml}$ & 3 & 122.3 & 0.53 \\
& & & \\
\hline
\end{tabular}

was characterized by a glass transition at $\mathrm{Tg}=12.6^{\circ} \mathrm{C}$ associated with the amorphous phase and a first-order transition attributed to the melting of the crystalline phase at $\mathrm{Tm}=105^{\circ} \mathrm{C}$. On the second DSC scan performed after quenching, the only evidenced was the glass transition phenomenon at $22.8^{\circ} \mathrm{C}$. On the electrospun $\mathrm{P}(\mathrm{LLA}-\mathrm{CL})$ thermograms, the glass transition on the first and second heating were detectable, but there was no evidence for a crystalline phase. The values of the glass transition determined from the second scan are pointed on the figure.

\section{Biological Assays}

At $24 \mathrm{~h}$ from seeding, cell adhesion on PCL significantly $(p<0.05)$ increased in all cultural conditions compared with that verified in control cultures without peptide (Figure 7). However, the covalent binding of the $\mathrm{N}_{3} R G D$ peptide on electrospun $P C L$ (samples $P_{C L} L_{D C M} 0.01 \mathrm{mg} / \mathrm{ml} ; P L_{D C M} 0.1 \mathrm{mg} / \mathrm{ml} ; P L_{D C M} 1 \mathrm{mg} / \mathrm{ml}$ ) significantly enhanced the adhesion of endothelial cells compared with the UV irradiated surface ( $\mathrm{PCL}_{\mathrm{DCM}} \mathrm{UV}$ ) and the scaffold with embedded peptide $\left(P C L_{\text {HFIP }} 1 \mathrm{mg} / \mathrm{ml}\right)$. Furthermore, the effect appeared to be dose-dependent and reached its maximum when pre-treated with a $1 \mathrm{mg} / \mathrm{ml}$ peptide solution $\left(\mathrm{PCL}_{\mathrm{DCM}} 1 \mathrm{mg} / \mathrm{ml}\right)$. Although cell proliferation was significantly higher in $\mathrm{PCL}$ containing peptide (samples $\mathrm{PCL}_{\mathrm{DCM}} 0.01 \mathrm{mg} / \mathrm{ml} ; \mathrm{PCL}_{\mathrm{DCM}} 0.1 \mathrm{mg} / \mathrm{ml}$; and $\mathrm{PCL}_{\mathrm{DCM}} 1 \mathrm{mg} / \mathrm{ml}$ ) compared with the proliferation observed on the polymer alone, after 7 days, no statistical differences were detected among scaffolds with embedded and covalently linked peptides. Thus, the effects of the biomimetic surfaces on cell proliferation were not as visible as those on cell adhesion. Overall, our data suggests that the covalent binding 


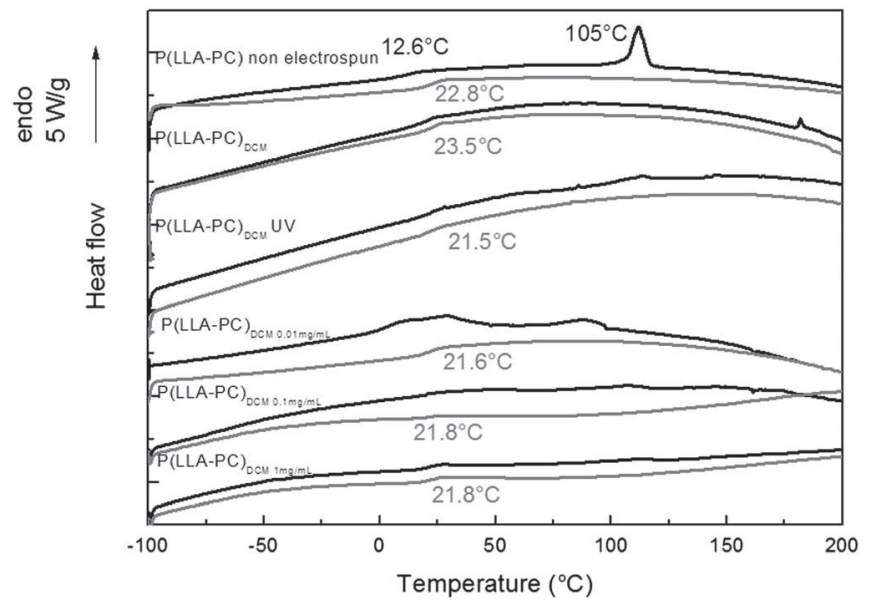

Figure 6. DSC thermograms (black line: 1st heating scan; gray line: 2nd heating scan) of $\mathrm{P}(\mathrm{LLA}-\mathrm{CL})$ samples. DSC, differential scanning calorimetry; $\mathrm{P}(\mathrm{LLA}-\mathrm{CL})$, poly(L-lactic acid-co-e-caprolactone).

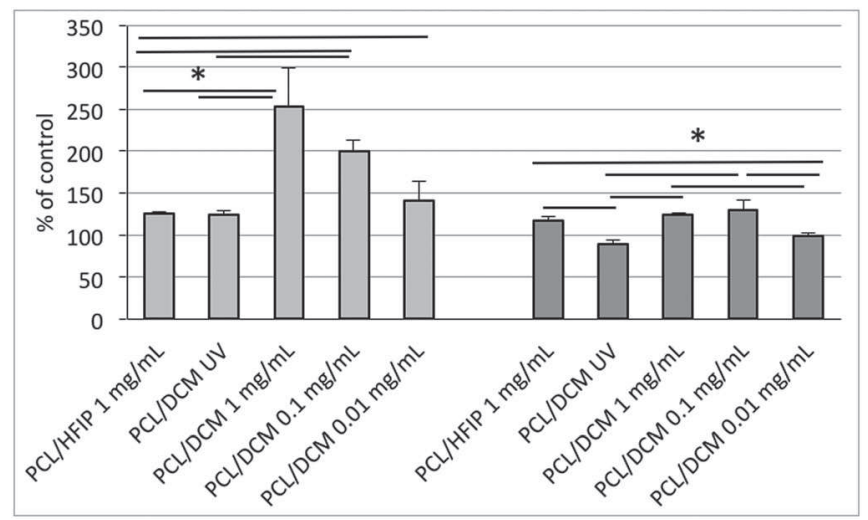

Figure 7. MTT assay at $24 \mathrm{~h}$ and 7 days from seeding on electrospun PCL. Results, expressed as percent of control cultures grown on polymers without peptides (taken as 100), are means \pm SD of three independent experiments. Bars: light gray $24 \mathrm{~h}$; dark gray 7 days. ${ }^{*} p<0.05$, Student's $t$-test.

approach is more valuable than simple embedding to induce endothelial cell adhesion.

Similar to that observed on $\mathrm{PCL}$, at $24 \mathrm{~h}$ from seeding, the covalent binding of the $\mathrm{N}_{3} R G D$ peptide on electrospun $\mathrm{P}(\mathrm{LLA}-\mathrm{CL})$ (samples $\mathrm{P}(\mathrm{LLA}-\mathrm{CL})_{\mathrm{DCM}} 0.01 \mathrm{mg} / \mathrm{ml} ; \mathrm{P}(\mathrm{LLA}-\mathrm{CL})_{\mathrm{DCM}} 0.1 \mathrm{mg} / \mathrm{ml}$; and $\mathrm{P}(\mathrm{LLA}-\mathrm{CL})$ DCM $1 \mathrm{mg} / \mathrm{ml}$ ) caused a significant $(p<0.05)$ increase in cell adhesion compared with the control cultures without peptide (Figure 8). Pretreatment with a $1 \mathrm{mg} / \mathrm{ml}$ peptide solution seemed to be the most effective concentration $\left(P(L L A-C L)_{D C M} 1 \mathrm{mg} / \mathrm{ml}\right)$, because the enhancement of cell adhesion was significantly higher than that verified on the UV-irradiated polymer ( $\left.(\mathrm{LLA}-\mathrm{CL})_{\mathrm{DCM}} \mathrm{UV}\right)$. At 7 days, cell proliferation was increased significantly with 1 and $0.1 \mathrm{mg} / \mathrm{ml}$ linked peptide compared with that verified on control and UVirradiated scaffolds.

\section{Discussion}

X-ray photoelectron spectroscopy data confirmed the possibility to anchor bioactive peptides on the surface of an electrospun biomaterial through the introduction in the peptide sequence of an azido group, which is converted by UV irradiation into a nitrene. The proposed strategy allows grafting the bioactive sequence to every type of surface in a one-step procedure. This method did not require the use of particular complementary functional groups on the surface. In addition, the introduction of the azido group in the side chain of each terminal residue, not involved in the bioactive sequence, ensures the specifically oriented grafting of the peptide. This method allows producing different peptide surface densities by simply modifying the peptide solution concentration used to treat the scaffold before UV-irradiation, while the efficiency of immobilization is low: the reaction yield is, even for the samples prepared with the highest peptide concentration solutions, less than $10 \%$ of the values calculated for the initial peptide quantity [20].

Our data showed that UV irradiation and peptide grafting on electrospun scaffolds did not produce important modifications in wettability and global thermal properties.

The effect of UV irradiation on polymeric surface wettability is controversial. Yeh et al. showed that even with a long time irradiation of PCL with UV at $254 \mathrm{~nm}$, no change is detected on the hydrophilicity of $\mathrm{PCL}$, i.e. the surface remains hydrophobic [21]. Furthermore, EC adhesion and proliferation may be improved by UVC irradiation (in the $172 \mathrm{~nm}$ range) or plasma treatment that increases the hydrophilicity of some polymer surfaces [22].

Surface wettability is an important property of biomaterials and can affect the attachment, proliferation, migration, and viability of cells. The water contact angle performed on dry surfaces can be used to evaluate wettability and surface modification and it can be compared with values from literature on different scaffolds. We chose to perform CA measurements with PBS instead of pure deionized (DI) water because PBS is a medium of interest for biological simulations, and PBS drops are already used in literature data [23]. Because surface tension of water only increases of about $0.4 \%$ in PBS, the errors that would be caused by the use of PBS are of the same order of magnitude as the statistical errors that usually occur in normal CA. So CA measurements in PBS are analogous to CA measurements in DI water [24].

All the samples showed a high level of hydrophobicity, with CA values of about $120^{\circ}$, with variations that do not exceed $4 \%$ and that cannot be associated with significant changes. Water CA values of about $70-74^{\circ}$ have been reported for flat $P C L$ films $[21,25]$ and of about $77^{\circ}$ for flat PLLA films [26]. In the case of electrospun $\mathrm{P}(\mathrm{LLA}-\mathrm{CL})$ scaffolds, the values of about $120^{\circ}$ certainly reflect a super hydrophobic behavior because of the specific roughness of the surface [27] as observed by SEM. It was already shown that post-electrospinning nanofibers of PCL could exhibit enhanced hydrophobicity [28]. Initial P(LLA-CL) are semi-crystalline. It has been previously proven by $\mathrm{X}$-ray diffraction in $\mathrm{P}(\mathrm{LLA}-\mathrm{CL})$ $70: 30$ that only lactide units were able to crystallize [29]. It was also reported that copolymerization of PLLA with CL had an important effect on the thermal properties; both the glass transition of the copolymer and the melting temperature of PLLA crystalline sequences decrease with the increase of the amount of $\mathrm{CL}$, because the introduction of $C L$ units, which have five methylene groups, increases the chain flexibility and mobility [30]. By comparison, with previous DSC studies on different P(LLA-CL) 70:30 copolymers, the commercial P(LLA-CL) 70:30 copolymer studied here is a moderately block polymer with a number average sequence length for LLA units between 4 and 3 [31]. At $37^{\circ} \mathrm{C}, \mathrm{P}(\mathrm{LLA}-\mathrm{CL}) 70: 30$ is in a visco-elastic state in contrast with pure PLLA $\left(\operatorname{Tg} \sim 60^{\circ} \mathrm{C}\right)$, which is glassy.

As evidenced on the first DSC thermogram of electrospun $P$ (LLA-CL) with the vanishing of the melting phenomenon and the persistence of the glass transition, electrospinning induces amorphization of the copolymer. The crystalline microstructure in 


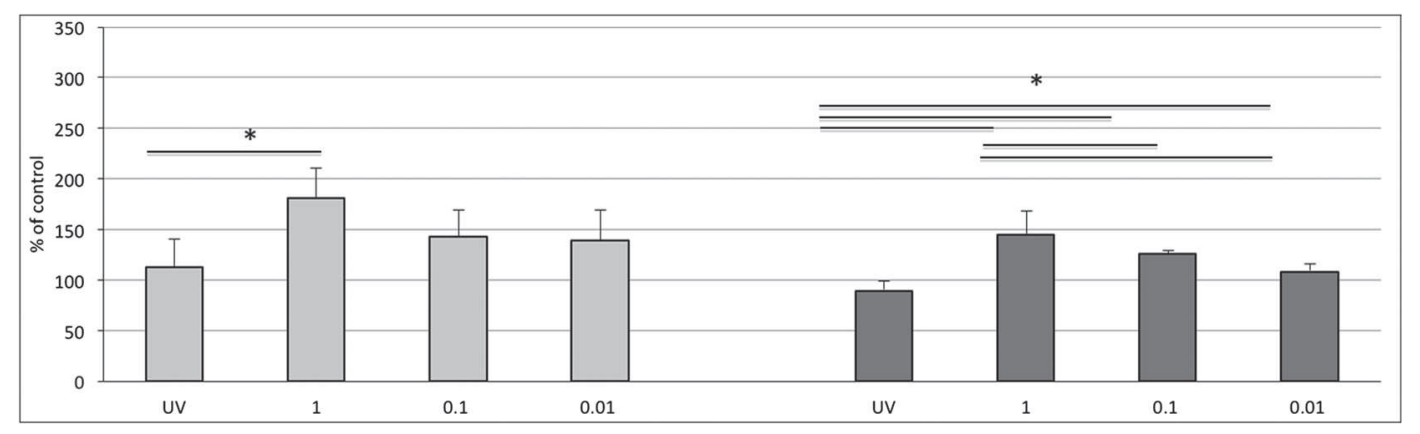

Figure 8. MTT assay at $24 \mathrm{~h}$ and 7 days from seeding on electrospun $\mathrm{P}(\mathrm{LLA}-\mathrm{CL})$. Results, expressed as percent of control cultures grown on polymers without peptides (taken as 100), are means \pm SD of three independent experiments. Bars: light gray $24 \mathrm{~h}$; dark gray 7 days; $1,0.1$, and 0.01 refer to the concentration in $\mathrm{mg} / \mathrm{ml}$ of $\mathrm{N}_{3} \mathrm{RGD}$ in the solution used for pretreatment before irradiation. ${ }^{*} p<0.05$, Student's $t$-test. The statistical comparison between cultures grown on electrospun PCL and $\mathrm{P}(\mathrm{LLA}-\mathrm{CL}$ ) (Figure 7) revealed that at $24 \mathrm{~h}$ from seeding, cell adhesion was higher on $\mathrm{P}(\mathrm{LLA}-\mathrm{CL})$ in $\mathrm{UV}$-irradiated cultures and in those containing the peptide, covalently linked with $0.01 \mathrm{mg} / \mathrm{ml}$ solution. On the contrary, no differences were detected when the (GRGDSP) ${ }_{4} \mathrm{~K}$ peptide was used at 1 and $0.1 \mathrm{mg} / \mathrm{ml}$. PCL, poly- $\varepsilon$-caprolactone; $\mathrm{P}(\mathrm{LLA}-\mathrm{CL})$, poly(L-lactic acid-co- $\varepsilon$-caprolactone).

electrospun fibers has often been reported as being not welldeveloped or totally inhibited [32].

As shown in Figure 6, UV irradiation induces a slight decrease $\left(-2^{\circ} \mathrm{C}\right)$ of the glass transition temperature, whereas peptide grafting does not result in further modifications of this parameter, meaning that the global thermal properties of the biomaterial are preserved.

While the functionalization process did not modify wettability and global thermal properties, it is important to underline that the different matrices used $\left(\mathrm{PCL}_{\mathrm{DCM}}, \mathrm{PCL}_{\mathrm{HFIP}}\right.$, and $\left.\mathrm{P}(\mathrm{LLA}-\mathrm{CL})_{\mathrm{DCM}}\right)$ were characterized by different initial fiber diameter and mesh dimension.

Biological assays demonstrated that in all cases, the peptide enrichment of the scaffolds increases HUVEC adhesion. The best results are obtained at the higher peptide solution concentration $(1 \mathrm{mg} / \mathrm{ml})$. This peptide incorporated to PCL did not give the same results. The different performance may be due to the random peptide presentation toward the cells, to the partial peptide presentation on the surface, and to de-adsorption of the embedded and non-covalently linked peptide. As demonstrated by the peptide release curve (Figure 5) registered for PCL $\mathrm{LFIP}_{1 \mathrm{mg} / \mathrm{ml}}$ sample, the concentration of the peptide in solution reached a constant value after $15 \mathrm{~h}$ : the quantity of peptide released was about one third of the initial peptide quantity. It is important to note that RGD peptides in solution could promote the inhibition of cell adhesion, an effect opposite to that induced by grafted RGD sequences. Arginine-Glycine-Aspartic Acid peptides acts as adhesion factors when chemically bound to the surface of biomaterials, or represents proapoptotic agents when used as soluble factors [33]. Indeed, they compete with ECM components for the binding to cell surface, thus inducing a lack of anchorage. In our previous work [34], we have demonstrated that (GRGDSP) ${ }_{4} \mathrm{~K}$ dissolved in culture medium inhibited the adhesion and proliferation of HUVECs. Consequently, this study provides further evidence on the superiority of covalent binding versus physical adsorption in the formulation of bioactive surfaces for tissue engineering or regenerative medicine applications.

The comparison between the two scaffolds functionalized with photoreactive peptides (Figure 9) showed no difference when treated with a higher concentration of peptide solution, but a better performance of the copolymer at the lower concentration of peptide solution or in the control surface, whether or not treated with UV irradiation. The difference can be due to the structure of the electrospun copolymer whose mesh dimensions are ideal for

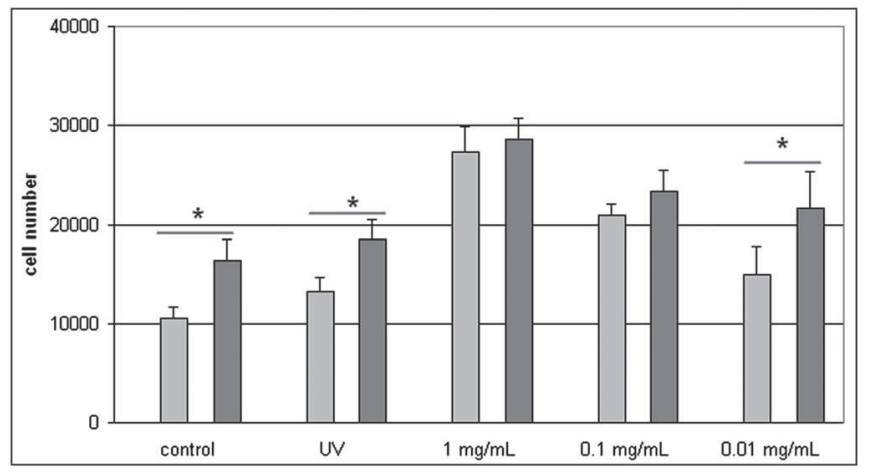

Figure 9. Comparison between electrospun $\mathrm{PCL}$ (light gray) and $\mathrm{P}(\mathrm{LLA}-\mathrm{CL})$ (dark gray) at $24 \mathrm{~h}$ from seeding. Results, expressed as cell number, are means \pm SD of three independent experiments. ${ }^{*} p<0.05$, Student's $t$-test. $\mathrm{PCL}$, poly- $\varepsilon$-caprolactone; $\mathrm{P}(\mathrm{LLA}-\mathrm{CL})$, poly(L-lactic acid-co- $\varepsilon$-caprolactone).

epithelial cells. In fact, endothelial cells prefer surfaces with porosity in the range of $18-60 \mu \mathrm{m}$ [9]. Also worth noting is the capacity of the biomimetic coverage to eliminate this difference at optimized peptide concentrations on the surface.

The scaffolds functionalized with photoreactive peptides seem to promote HUVEC adhesion more than HUVEC proliferation. In view to blood vessel replacement, a key factor is a quick reendothelization of biomaterials, because the coverage with endothelial cells avoid platelet adhesion and, in turn, thrombus formation. On the other hand, cell growth is an event that takes place after adhesion but it is not particularly desired for our aims: proliferation of endothelial cells, seeded on the biomimetic scaffold, could cause intimal hyperplasia and finally blood vessel obstruction.

In the past, the functionalization of biomaterials with adhesive peptides has raised some skepticism. The perplexity concerns the efficacy of such strategy in in vivo contexts due to serum proteins adsorption on the functionalized surface. Recently, Battista E. et al. [35], engrafting an RGD peptide on PCL surfaces, demonstrated that the presence of serum proteins effectively creates a layer that covers peptide covalently conjugated on the surface but, after the first adhesion phase, cells dig into the physisorbed protein layer and reach the submerged RGD peptide for establishing a more stable adhesion. The driving force of the process is the preference by cells for adhering on firmly bound RGD on which to build more robust focal adhesions and a mechanically stable cytoskeleton via mechanosensing mechanism. The data reported [35] are in 
agreement with our results [36] demonstrating that the covalent functionalization of biomaterials with adhesive peptides increases cell adhesion but also adhesion strength. In addition, the preference by cells for firmly bound RGD could explain the different performance of covalent grafted RGD versus embedded RGD.

These new experimental evidences shed light on the mechanisms that give rise to the behavior of the cells seeded on functionalized surfaces; support the efficacy of the covalent conjugation of adhesive motifs also in the presence of serum and open new perspectives in the development of biomaterials decorated with finely tuned ligands able to support the assembly of the cell cytoskeleton in a controlled manner.

\section{Conclusions}

The use of azido-tagged peptides allows the surface modification of electrospun matrices. The covalent anchoring by activation of the azido groups with ultraviolet radiation is preferable to the simple inclusion of the adhesive peptides in the electrospun scaffold as regards the promotion of cell adhesion. While not being particularly efficient, the proposed method is simple, versatile, and able to provide matrices with different degree of functionalization (peptide density) and to assure the selective grafting of the adhesive peptides. Although the matrices used in this study showed similar thermal and surface properties, they have different morphological characteristics. Nevertheless, the covalent functionalization with adhesive peptides seems to be the dominant factor in the outcome of the bioassay.

\section{Acknowledgements}

The authors would like to thank Dr Paolo Pontini for his help in the preparation of the scaffolds.

\section{References}

1 Hirsch AT, Allison MA, Gomes AS, Corriere MA, Duval S, Ershow AG, Hiatt WR, Karas RH, Lovell MB, McDermott MM, Mendes DM, Nussmeier NA, Treat-Jacobson D. A call to action: women and peripheral artery disease: a scientific statement from the American Heart Association. Circulation 2012; 125: 1449-1472. DOI: 10.1161/ CIR.0b013e31824c39ba.

2 Piccone V. Alternative techniques in coronary artery reconstruction.In Modern Vascular Grafts, McGraw-Hill Book Company: New York, NY, 1987; 253-260.

3 Neff LP, Tillman BW, Yazdani SK, Machingal MA, Yoo J, Soker S, Bernish BW, Geary RL, Christ GJ. Vascular smooth muscle enhances functionality of tissue-engineered blood vessels in vivo. J. Vasc. Surg. 2011; 53: 426-434. DOI: 10.1016/j.jvs.2010.07.054.

4 Thomas AC, Campbell GR, Campbell JH. Advances in vascular tissue engineering. Cardiovasc. Pathol. 2003; 12: 271-276. DOI: 10.1016/ S1054-8807(03)00086-3.

5 Nemeno-Guanzon JG, Lee S, Berg JR, Jo YH, Yeo JE, Nam BM, Koh YG, Lee Jl. Trends in tissue engineering for blood vessels. J. Biomed. Biotechnol. 2012; 2012: 956345. DOI: 10.1155/2012/956345.

6 Hung HS, Chen HC, Tsai CH, Lin SZ. Novel approach by nanobiomaterials in vascular tissue engineering. Cell Transplant. 2011; 20: 63-70. DOI: $10.3727 / 096368910 \times 532864$.

7 Conconi MT, Borgio L, Di Liddo R, Sartore L, Dal ZD, Amistà P, Lora S, Parnigotto PP, Grandi C. Evaluation of vascular graft based on polyvinyl alcohol cryogels. Mol. Med. Rep. 2014; 10: 1329-1334. DOI: 10.3892/mmr.2014.2348.

8 Dettin M. Bioactive surfaces using peptide grafting in tissue engineering. In Cellular Response to Biomaterials, Woodhead Publishing Limited CRC Press: Cambridge, UK, 2009; 479-502.

9 Andrews KD, Hunt JA. Developing smaller-diameter biocompatible vascular grafts.In Cellular Response to Biomaterials, Woodhead Publishing Limited, CRC Press: Cambridge, UK, 2009; 212-233.
10 Liu W, Thomopoulos S, Xia Y. Electrospun nanofibers for regenerative medicine. Adv. Healthc. Mater. 2012; 1: 10-25. DOI: 10.1002/ adhm.201100021.

11 Pankajakshan D, Agrawal DK. Scaffolds in tissue engineering of blood vessels. Can. J. Physiol. Pharmacol. 2010; 88: 855-867. DOI: 10.1139/ y10-073.

12 Zhao Y, Zhang S, Zhou J, Wang J, Zhen M, Liu Y, Chen J, Qi Z. The development of a tissue-engineered artery using decellularized scaffold and autologous ovine mesenchymal stem cells. Biomaterials 2010; 31: 296-307. DOI: 10.1016/j.biomaterials.2009.09.049.

13 Monchaux E, Vermette P. Effects of surface properties and bioactivation of biomaterials on endothelial cells. Front. Biosci. 2010; 2: 239-255.

14 Li J, Ding M, Fu Q, Tan H, Xie X, Zhong Y. A novel strategy to graft RGD peptide on biomaterials surfaces for endothelization of small-diameter vascular grafts and tissue engineering blood vessel. J. Mater. Sci. Mater. Med. 2008; 19: 2595-2603. DOI: 10.1007/s10856-007-3354-5.

15 Dettin M, Conconi MT, Gambaretto R, Pasquato A, Folin M, Di Bello C, Parnigotto PP. Novel osteoblast-adhesive peptides for dental/orthopedic biomaterials. J. Biomed. Mat. Res. 2002; 60: 466-471.

16 Dettin M, Conconi MT, Gambaretto R, Bagno A, Di Bello C, Menti AM, Grandi C, Parnigotto PP. Effect of synthetic peptides on osteoblast adhesion. Biomaterials 2005; 26: 4507-4515.

17 Grant GA. Synthetic Peptides: A User's Guide, Oxford University Press: New York, 2002; 328-329.

18 Woulters W, Van Dun J, Laduron PM. Photoaffinity labelling of dopamine receptors. Synthesis and binding characteristics of azapride. Eur. J. Biochem. 1984; 145: 273-278.

19 Moulder JF, Stickle WF, Sobol PE, Bomben KD. Handbook of X-ray Photoelectron Spectroscopy, Physical Electronics Inc. eds: Eden Prairie, MN, 1996.

20 lucci G, Ghezzo F, Danesin R, Modesti M, Dettin M. Biomimetic peptideenriched electrospun polymers: a photoelectron and infrared spectroscopy study. J. Appl. Pol. Sci. 2011; 122: 3574-3582.

21 Yeh C-C, Chen C-N, Li Y-T, Chang C-W, Cheng M-Y, Chang H-I. The effect of polymer molecular weight and UV radiation on physical properties and bioactivities of PCL films. Cellular Polymers 2011; 30: 227-242.

22 De Mel A, Jell G, Stevens MM, Seifalian AM. Biofunctionalization of biomaterials for accelerated in situ endothelialization: a review. Biomacromolecules 2008; 9: 2969-2979. DOI: 10.1021/bm800681k.

23 Kim J, Shen AQ, Lee KH, Cangelosi GA, Chung JH. Contact angle changes induced by immunocomplex formation. Analyst 2014; 139: 1340-1344. DOI: $10.1039 / \mathrm{c} 3 a n 02189 \mathrm{k}$.

24 Van Oss CJ. The Properties of Water and Their Role in Colloidal and Biological Systems, Academic Press, Elsevier: Amsterdam, Holland, 2008; 160.

25 Chung T-W, Yang M-G, Liu D-Z, Chen W-P, Pan C-I, Wang S-S. Enhancing growth human endothelial cells on Arg-Gly-Asp (RGD) embedded poly ( $\varepsilon$-caprolactone) (PCL) surface with nanometer scale of surface disturbance. J. Biomed. Mater. Res. 2005; 72A: 213-219.

26 Cui YL, Di Qi A, Liu WG, Wang XH, Wang H, Ma DM, De Yao K. Biomimetic surface modification of poly(l-lactic acid) with chitosan and its effects on articular chondrocytes in vitro. Biomaterials 2003; 24: 3859-3868.

27 Yoshimitsu Z, Nakajima A, Watanabe T. Effects of surface structure on the hydrophobicity and sliding behavior of water droplets. Langmuir 2002; 18: $5818-5822$

28 Bosworth L, Downes S. Biocompatible Three-Dimensional Scaffolds for Tendon Tissue Engineering using Electrospinning, in Cellular Response to Biomaterials, Elsevier: Amsterdam, Holland, 2008; 1-27.

29 Ugartemendia JM, Sarasua JR, Proceedings of the 69th Annual Technical Conference of the Society of Plastic Engineering ANTEC 2011; 1: 230.

30 Lu XL, Sun ZJ, Cai W, Gao ZY. Study on the shape memory effects of poly (L-lactide-co-epsilon-caprolactone) biodegradable polymers. J. Mater. Sci. Mater. Med. 2008; 19: 395-399.

31 Fernández J, Etxeberria A, Ugartemendia JM, Petisco S, Sarasua J-R. Effects of chain microstructures on mechanical behavior and aging of a poly(L-lactide-co- $\varepsilon$-caprolactone) biomedical thermoplasticelastomer. J. Mech. Behav. Biomed. Mater. 2012; 12: 29-38. DOI: 10.1016/j.jmbbm.2012.03.008.

32 Zong X, Ran S, Fang D, Hsiao BS, Chu B. Control of structure, morphology and property in electrospun poly(glycolide-co-lactide) non-woven membranes via post-draw treatments. Polymer 2003; 44: 4959-4967.

33 Swenson S, Ramu S, Markland FS. Anti-angiogenesis and RGD containing snake venom disintegrins. Curr. Pharm. Des. 2007; 13: 2860-2871.

34 Conconi MT, Ghezzo F, Dettin M, Urbani L, Grandi C, Guidolin D, Nico B, Di Bello C, Ribatti D, Parnigotto PP. Effects on in vitro and in vivo 
angiogenesis induced by small peptides carrying adhesion sequences. J. Pept. Sci. 2010; 16: 349-357. DOI: 10.1002/psc.1251.

35 Battista E, Causa F, Lettera V, Panzetta V, Guarnieri D, Fusco S, Gentile F, Netti PA. Ligand engagement on material surfaces is discriminated by cell mechanosensoring. Biomaterials 2015; 45: 72-80. DOI: 10.1016/j. biomaterials.2014.12.012
36 Bagno A, Piovan A, Dettin M, Brun P, Gambaretto R, Palù G, Di Bello C, Castagliuolo I. Improvement of Anselme's adhesion model for evaluating of human osteoblast response to peptide-grafted titanium surfaces. Bone 2007; 41: 704-712. 